R. Zhyvotovskyi ${ }^{1}$, O. Momit ${ }^{2}$, Ya. Onbinskyi ${ }^{3}$, A. Lyashenko ${ }^{4}$

${ }^{1}$ Central research institute of weapons and military equipment of armed forces of Ukraine, Kyiv, Ukraine

${ }^{2}$ Military unit A 2393, Odessa, Ukraine

${ }^{3}$ General Directorate of the National Guard of Ukraine, Kyiv, Ukraine

${ }^{4}$ Military institute of telecommunications and informatization named after Heroes of Kruty, Kyiv, Ukraine

\title{
ANALYSIS OF THE KNOWN METHODS OF CHANNELS COMMUNICATION CONTROL WITH THE INTERFERENCE AND SELECTIVE FADING
}

\begin{abstract}
Designing adaptive radio systems, depending on their purpose, solves the problem of optimizing one of the performance indicators with restrictions on others. In turn, the development and implementation of adaptive information sharing techniques require the establishment of effective procedures for monitoring and predicting the status of communication channels and the quality of information transmission. Given the rapid development of electronic warfare facilities, the expansion of the list of interferences that can be created by these complexes, it is great relevance for further scientific research on the creation of new methods of monitoring the status of the communication channel. In this research, the authors analyzed the characteristics of the main methods for assessing the status of communication channels. In the course of the analysis, the authors used general scientific methods of analysis and synthesis, the basic provisions of communication theory, data transfer theory, space-time coding theory, noise immunity theory, signal-code theory, etc. The authors of the article analysis of the known methods of estimating the state of the channel of multi-antenna communication systems showed that the known scientific articles do not contain the following: parallel estimation of the status of the channel by several indicators; obtaining a generalized channel status assessment; continuous evaluation of several characteristics in real-time; at the same time evaluate both the lines down and the lines up; the combination of the impulse response of the channel state, the frequency response of the channel status, and the bit error probability is not used for the estimation. It is established that at present there is no universal method of monitoring the status of channels of multiantenna radio communication systems, which would give an accurate, fast estimate of the status of the channel in real-time, which would allow effective adaptation in a channel with non-stationary parameters.
\end{abstract}

Keyw ords : signal-to-noise ratio; data rate; bit error probability; space-time processing; MIMO system; parallel channels.

\section{Introduction}

MIMO (Multiple Input Multiple Output) has found practical application in many modern telecommunications systems. MIMO is used in IEEE 802.11n wireless LANs, as well as WIMAX and LTE wireless networks, etc. [1-5].

The essence of MIMO technology is similar to the method of diversity reception, when several uncorrelated copies of the signal are created on the receiving side due to the spacing of the antennas in space, by polarization, the diversity of the signals in frequency or in time.

In MIMO radio systems, spatial multiplexing is implemented: a data stream in the transmission is splitted into two or more sub-streams, each transmitted and received by different antennas [1-10].

The noise immunity of multi-antenna radio systems is affected by deliberate interference and signal fading that occur during multipath propagation. In order to ensure stable radio communication under active electronic suppression and selective fading, the radio system must have signal and interference information in the channel.

The development of devices of electronic warfare, the imperfection of known methods (techniques) for assessing the status of channels in MIMO systems necessitates the search for new scientific approaches to increase the immunity of MIMO systems to the required level.

In order to reduce the time of adaptation of the radio communication equipment in the conditions of the influence of electronic warfare, it is necessary to reduce the time for the assessment of the condition of the channel, while maintaining the necessary reliability. Also, it is necessary to develop new methods for assessing the status of the channel.

All this confirms the relevance of the chosen research direction.

While designing adaptive radio systems, depending on their purpose, solves the problem of optimizing one of the performance indicators with restrictions on others. In turn, the development and implementation of adaptive information sharing techniques require the establishment of effective procedures for monitoring and predicting the status of communication channels and the quality of information transmission. In order to solve this problem, it is necessary to involve methods of modern mathematical statistics, in particular, to test the statistical hypotheses regarding the parameter (parameter group) that characterizes the state of the communication channel.

The purpose of this article is to conduct an analysis of known channel monitoring techniques for multi-antenna systems for intentional interference and selective fading.

Presentation of main material research

Different types of control can be classified by purpose, time of connection of control devices, method of receiving and source of information, a form of presentation of initial information, relation to the process of information transfer, method of implementation of procedures [9].

On target features distinguish the control:

warning, which is performed to determine the characteristics of various disturbing factors (channel 
error rate, failure rate of equipment), necessary for the development of efficient algorithms for exchange and resource management, is characterized by the presence of a large number of control equipment and is available on free channels allocated for research on long hours (hundreds and thousands of hours);

functional, which is performed to determine the degree of compliance of the partial parameters of the channels and all equipment to the set standards and to regulate the equipment in case of non-compliance. Functionally monitored channels are not used to transmit information during the entire control period, which lasts from ten minutes to several hours;

operational, which is organized to accurately assess the current status and interference situation in channels and paths engaged in the transmission, as well as to evaluate the quality of transmission over time, compared to the duration of the exchange cycle. The control is necessary for the prompt check of the readiness of the equipment and organization of the operational management of system resources for the purpose of adaptation to changes of the operating conditions, differs in the variety of forms of gathering and submission of information, depending on the type of controlled equipment (quality indicator) and the criterion on the basis of which the choice is made.

Connection time distinguishes the control:

continuous, at which the control devices are constantly connected to the controlled equipment;

periodic, which is used when a single control device is used to determine the status of several functional devices. The most characteristic of preventive and functional control.

The following types of controls can be distinguished by the method of obtaining and the source of information:

test is a certain sequence of characters is fed to the input of the equipment (channel, track) and the internal condition and interference situation are evaluated by their acceptance (usually used to check the performance of the whole system of transmitting discrete information at the beginning of its operation and when there are "pauses" in information exchange);

indirect is a source of information is a distortion of signal parameters, streams of decisions of all kinds of quality detectors, the first decisive scheme for acceptance with erasures;

code is a source of information is the sequence of decisions of the decoder of the second decisive circuit;

direct measurement is an individual equipment parameters, noise levels, signal-to-noise ratios, etc. can be directly measured by special devices; It is widely used in functional control and in radio systems with frequency adaptation.

Indirect and code-based methods are used mainly in operational control.

The main forms of output for radio communication systems (RCS) are an evaluation of system function; values of the quality criterion, estimation of parameters of the distribution of errors, interferences; evaluation of noise distribution functions; a conclusion on working capacity; The „,coordinates” of the failing elements and devices. The necessary form of initial information is determined by the purpose of control and provided by the selected mathematical apparatus.

Dynamic quality control of radio channels is required to implement the adaptive principle of RCS parameters and resources management [5, 10, 12]. Operational control is organized to improve the reliability of the assessment of the current status and interference situation in the channels and transmission paths, as well as to evaluate the quality of transmission over time comparable to the duration of the information exchange cycle.

There are two main ways to control the status of a radio channel at this time. The first involves estimating the channel status based on control of the primary signal and interference parameters: amplitude, smoothed amplitude (level), duration, a ratio of amplitudes or signal and interference levels, and the like. The second method is based on obtaining an estimate by analyzing the secondary parameters: the frequency of errors in the reception of the message symbols, the number of requests in systems with decisive feedback, different code features, etc. The classification of the statistical characteristics of the communication channels is shown in Fig. 1.

Because the secondary parameters are less informative, some time spending are required to obtain sufficient estimation accuracy, which cannot be taken into account only if the channel state is slow enough to change the message rate. Primary characteristics mainly reflect the causes of signal distortion, instability of carrier generators, phase jumping and jitter, fading and changes of residual attenuation, fluctuation noises, impulse and harmonic interference, interruptions and nonlinear distortions. The non-ideality of the frequency and amplitude characteristics arises due to the regular distortion of only regular signals. While transmitting random (information) sequences, distortions are stochastic because their magnitude depends on the type (shape) of the signal.

The characteristics of the signal at the output of the decoder are called secondary. They reflect the degree of distortion of single elements and include boundary distortions, crushes, and mass distortions. The most complete characteristic of the quality of a discrete channel is the statistics of errors that occur while transmitting information.

For modern military radio systems, the first way to control the status of radio channels is definitely more effective.

The main requirements for such control are the high accuracy and efficiency of the analysis, as well as a fairly simple implementation of computing processes on electronic computers.

In this case, the calculation of the corresponding estimated values can occur either by devices of special measuring signals or directly in the process of transmitting operational information $[10,12]$.

All estimation methods, which are used today in radio communication systems can be divided into 4 groups according to the following scheme shown in Fig. 2.

Let's look at these methods in more details. 


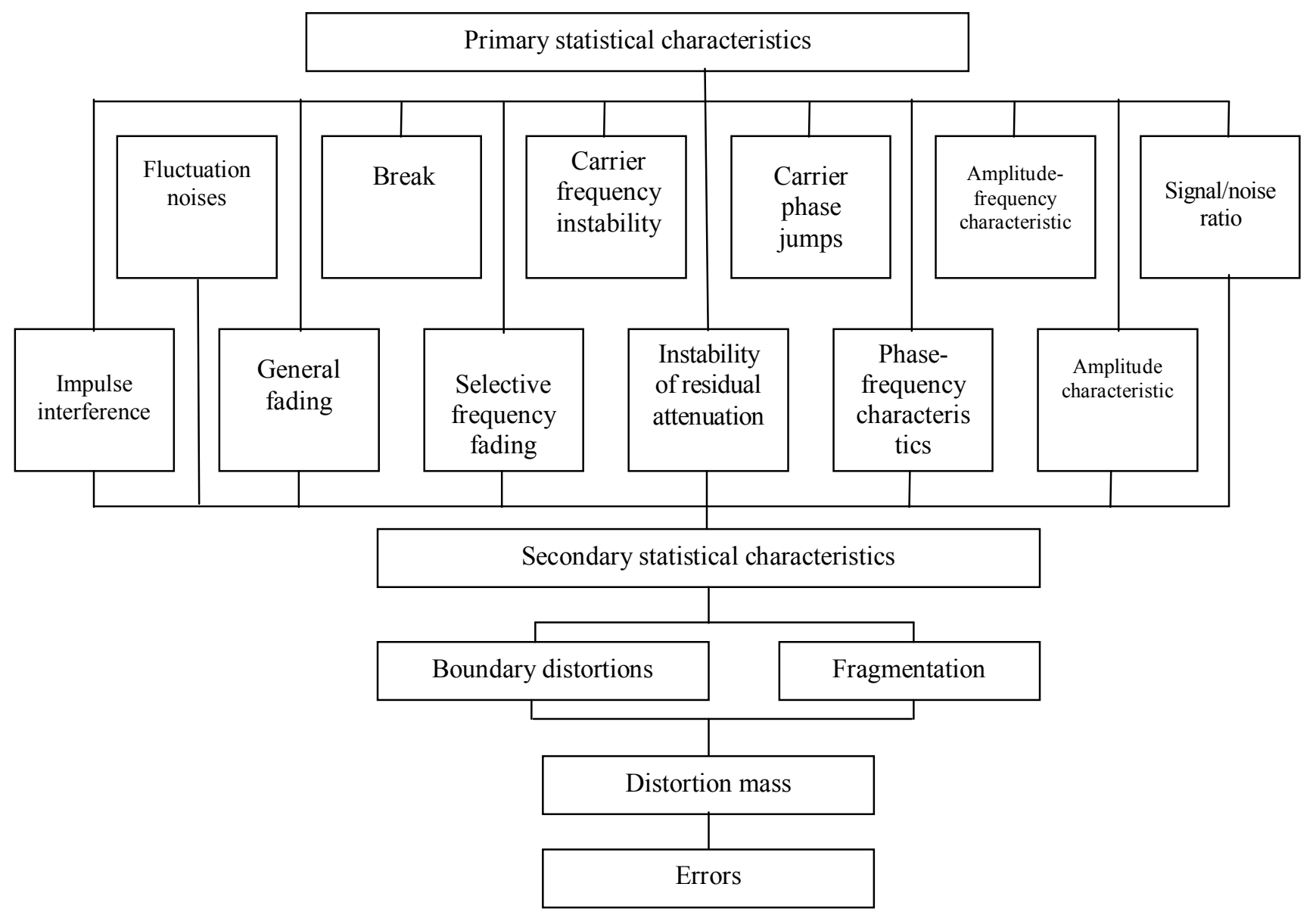

Fig. 1. Communication channel statistics

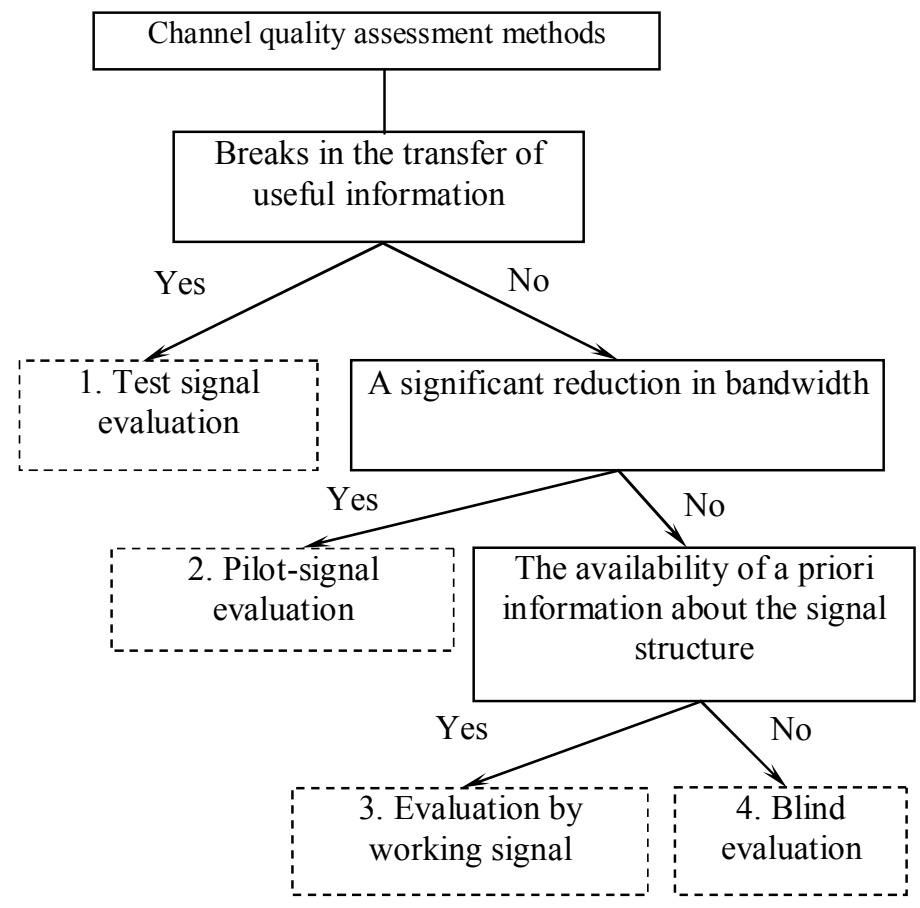

Fig. 2. Classification of channel quality assessment methods

1. One of the least critical to the computational complexity of algorithms is a method based on the periodic transmission of test signals of a known structure or probing pulses. The essence of the method 
is that at the same intervals, the transmitter generates at its output special test signals (pseudorandom sequence (PRS)), which, passing through the communication channel, arrive at the input of the receiving equipment and then to the evaluation scheme, which by implication comparison of the parameters of the received test signal with the parameters of the reference signal produced by its own generator, estimates the state of the channel as a whole. The distortion and interference occurring in the communication channel change the level of the test signal, which allows to determine the signal/interference ratio in the channel, and the measurement of the offset of the boundaries of the bit intervals PRS allows to conclude the magnitude of the time delay of the signal.

The disadvantage of this method is that at the time of transmission of the test sequence, the transfer of useful information, which reduces the speed of information transmission. The transmission time of the test sequence is also increased by performing the procedure of synchronization of the receiving and transmitting paths. In addition, the evaluation of the test signal provides information only at the time of its passage through the communication channel, which is reflected in the timeliness of the received evaluation, because during the assessment of the condition of the channel propagation conditions in a multipath radio channel can change dramatically and a good quality channel may be completely unsuitable for transmitting information .

2. The use of a transmitted message in pilots located at strictly defined time positions and with some fixed parameters, allows the receiving equipment to distinguish them from the composition of the received message against the background of noise and to analyze the parameters of the pilot tones communication channel as a whole. Fixing and evaluating the reception of the one after the other as part of the pilot's signal allows us to characterize the frequency and time delays in the channel by analyzing the offset of the clock limits, which ultimately gives information about the quality of the communication channel.

While changing the parameters of the pilot signals (position in the structure of the signal, the type of modulation, its multiplicity, the signal level) allows to obtain information about the status of the channel in the conditions of concentrated noise interference by moving the pilot tones to temporal positions free from the influence of interfering noise. At the same time, the frequency of receipt of pilots and the fixation of their time positions serves to perform the synchronization procedure.

In addition, the transmission of pilot signals allows timely determination of the conditions of propagation of changing signals, on the basis of which the adaptation scheme can adjust the transmission parameters in order to achieve the desired level of confidence. However, since the pilot tones are contained in each frame of the transmitted message, together with their useful properties, they reduce the bandwidth of the communication system. Due to the ease of isolation and estimation of the parameters of the pilot tones, this method has a rather low computational complexity, and their transmission in the composition of the information signal provides the efficiency of estimation of the quality of the channel.

3. While using the methods of estimating the quality of the channel on the working signal to assess the status of the channel at the reception implement the input information signal, adopted in the conditions of action of various interferences and prone to distortion.

This type of evaluation requires a priori knowledge of the recipient of some information about the transmitted signal, such as the type and frequency of modulation, the value of the length of the loop prefix, etc.

The type and multiplicity of modulation determines the type of signal constellation used to represent the signal, which at the reception makes it possible to measure the dispersion of the points of the phase plane corresponding to the transmitted information symbols, and, given some critical values of this scattering, we can conclude the quality of the communication channel .

Knowledge of the length of the cyclic prefix allows you to determine the offset of the boundaries of the characters of the protective interval, which allows you to estimate the time and frequency delay signal. The algorithm for doing signal estimation allows to receive a timely and prompt estimation of channel quality. One of the main advantages of this method of assessment is that it does not affect the transmission capacity of the transmission system in a timely and prompt receipt of the assessment, which in today's conditions of development of high-speed services becomes very relevant.

4. Blind evaluation refers to the evaluation of unknown signals that have passed a linear channel with unknown characteristics against the background of interference [9]. In this case, the estimation of the signal parameters is conducted only on the available implementations of the input signal of the receiving device.

There is a huge variety of channel blind estimation methods, the use of which is based on the application of statistical blind identification methods and various mathematical methods, which requires a large computational cost to accumulate and process a statistically significant number of implementations. Due to the need for prior accumulation of data to analyze the quality of the channel, this algorithm has rather low efficiency and timeliness of the evaluation. In the general case, in the case of a blind evaluation, only an approximate solution of the best in terms of some quality criterion can be obtained. The undoubted advantage of the blind estimation algorithm is that the channel estimation is conducted without the use of methods that reduce the transmission capacity of the transmission system.

While using different methods of signal quality assessment in adaptive communication systems, it is possible to transmit the received information about the status of the communication channel on the dedicated service channel to the transmitter, which on the basis of these data can change the parameters of the transmitted 
signal, thereby providing the optimum for specific conditions spreading noise immunity. However, organizing a counter feedback channel requires a transmission system bandwidth, which is a negative factor.
The advantages and disadvantages of these methods are summarized in Table 1.

Thus, the following conclusions can be drawn from known methods of assessing the status of a communication channel.

Table 1 - Comparative characteristics of channel status estimation methods

\begin{tabular}{|l|c|c|c|c|}
\hline $\begin{array}{c}\text { Characteristic } \\
\text { of the method }\end{array}$ & $\begin{array}{c}\text { Test } \\
\text { sequence }\end{array}$ & $\begin{array}{c}\text { Pilot } \\
\text { signals }\end{array}$ & $\begin{array}{c}\text { By working } \\
\text { signal }\end{array}$ & $\begin{array}{c}\text { Blind } \\
\text { evaluation }\end{array}$ \\
\hline $\begin{array}{l}\text { Computational } \\
\text { complexity }\end{array}$ & low & low & high & high \\
\hline $\begin{array}{l}\text { Effectiveness } \\
\text { of assessment }\end{array}$ & low & high & high & medium \\
\hline $\begin{array}{l}\text { Timeliness } \\
\text { of evaluation }\end{array}$ & low & decrease & a slight decrease & no impact \\
\hline $\begin{array}{l}\text { Impact } \\
\text { on bandwidth }\end{array}$ & break in transmission \\
\hline
\end{tabular}

1. While designing adaptive radio systems, the channel signal quality estimation method should be used because it does not reduce the bandwidth of the radio system and provides prompt and timely acquisition of channel status information at acceptable computational costs.

2. While establishing a link or restoring it after a forced break, when the transmission of useful information with given reliability is not possible in principle, the method of using a test sequence implemented on the basis of a simple but low-speed implementation scheme should be used to evaluate the quality of the channel.

3. After establishing communication or improving channel quality in the course of transmitting operational information to obtain timely and operational estimates of acceptable quality due to some system bandwidth costs and using a simple and high-speed estimation scheme, a pilot method may be used, the number of which may be reduced as the channel quality improves.

4. In the high-quality channel conditions, it is possible to switch to blind channel quality estimation using a sophisticated and non-operational implementation scheme.

However, in these circumstances, due to the complete rejection of the bandwidth consumption of the system to study the channel characteristics, the system performance on the bandwidth indicator will be the highest. It is also possible to share methods using the RTSE, such as working and pilot signal estimation methods. In this case, several pilot signals are introduced into the signal structure, which does not significantly influence the bandwidth, but allow to clarify the estimates obtained by the working signal estimation method, and, in addition, to reduce the impact of the pilots in the signal structure focused channel quality interference. It is also possible to use combined channel quality estimation methods while using the working signal estimation method as a reference, a test signal is transmitted in the absence of useful information to the communication channel to clarify the characteristics of the signal propagation environment.

A feature of a multipath channel is its nonstationarity due to the presence in the channel of constant changes in the conditions of signal propagation, which leads to distortions of the transmitted signal. In addition to distortions due to the special nature of the propagation of radio waves, the transmitted signal may be affected by deliberate and accidental interference.

One of the most important prerequisites for designing adaptive systems is the need for real-time channel estimation (RTCE) quality. The data obtained during the RTCE procedure can be used to perform adaptation procedures, so a process related to the automatic change of operating parameters and/or system configuration in response to changes in the timing of signal propagation in the channel and the intensity of external noise and interference. Performing the adaptation procedure ensures the best quality of the received radio signal under the specified propagation conditions. Timely and accurate assessment of the quality of the channel allows us to adapt the signals to the changing conditions of distribution and interference with the channel and, accordingly, to maintain the quality of service at the proper level.

In the process of data transmission by radio channels, the main sources of error in the received messages are signal distortions caused by the influence of the conditions of propagation of radio waves, such as fading and multipath, as well as the effect on this background of narrow-band or spectrum-focused interference.

Solving the problem of detecting and estimating intentional interference in the channel requires strict determination of the use of detection methods and simultaneous estimation of the signal with unknown parameters. For adaptation purposes, it is the first and foremost necessary to identify strong interferences and evaluate their impact on the accuracy of the received information. 
In the work [10] it is shown that in the channels with slow fading, abrupt changes in the levels of the received signal at the output of the frequency channel of the demodulator affected by the spectrum-focused interference is a sign of identification of this frequency channel as affected by the amplitude-modulated interference.

The method of statistical estimation, which uses the threshold of the control channel voltage to make decisions about the presence of a demodulator error, ensures the adequacy of the generated estimates in the interference environment. The control channel voltage threshold corresponds to the calculated error probability.

Simultaneously obtaining estimates of the quality of the channel and the concentrated interference during a single computing procedure, which is performed while demodulating the received signal, saves the total computational resource of the processor.

\section{Conclusions}

The authors analyzed the methods of monitoring the status of channels of multi-antenna communication systems.
Therefore, an analysis of known methods of assessing the condition of the channel of the MIMO system showed that in these works there is no:

- parallel evaluation of the status of the channel on several indicators;

- getting a generalized channel status estimate;

- continuous evaluation of several characteristics in real-time;

- at the same time evaluate the lines down and the lines up;

- the combination of the impulse response of the channel state, the frequency response of the channel status, and the bit error probability is not used for the estimation [1-14].

It is established that at present there is no universal method of monitoring the status of channels of multiantenna radio communication systems, which would give an accurate, fast estimate of the status of the channel in real-time, which would allow effective adaptation in a channel with non-stationary parameters.

The direction of further research should be the development of a method for estimating the status of a multi-antenna radio communication channel in the conditions of electronic counteraction.

\section{REFERENCES}

1. Shyshatskiy, A.V., Bashkirov, O.M. and Kostina, O.M. (2015), "Development of integrated systems and data for Armed Forces", Arms and military equipment, No 1(5), pp. 35-40. available at: http://journals.uran.ua/index.php/24140651/issue/view/1\%285\%29\%202015 (last accessed October 22, 2019).

2. Vishnevskiy, V. M., Lyahov, A. I., Portnoy, S. L. and Shahnovich I. V (2005), Broadband wireless communication networks, Moscow.: Technosphere, $592 \mathrm{p}$.

3. Volkov, L.N., Nemirovkiy, M.S. and Shinakov, Yu.S. (2005) Digital radio communication systems: basic methods and characteristics: a tutorial,. Moscow, Eco-Trends, 392 p.

4. Goldsmith A. (2011) Wireless communications, Moscow., Technosphere, 904 p.

5. Slusar V. (2005) "MIMO systems: principles of construction and signal processing", Electronics: science, technology, business, No 8., pp. 52-58, available at http://www.electronics.ru/files/article_pdf/0/article_974_409.pdf (last accessed October 22, 2019).

6. Kalantaievska, S., Pievtsov, H., Kuvshynov, O., Shyshatskyi, A., Yarosh, S., Gatsenko, S., Zubrytskyi, H., Zhyvotovskyi, R., Petruk, S. and Zuiko, V(2018). "Method of integral estimation of channel state in the multiantenna radio communication systems". Eastern-European Journal of Enterprise Technologies, Vol 5, No. 9 (95): pp 60-76. DOI: https://doi.org/10.15587/1729-4061.2018.144085.

7. Ehab M. Shaheen, Mohamed Samir (2013), "Jamming Impact on the Performance of MIMO Space Time Block Coding Systems over Multi-path Fading Channel", REV Journal on Electronics and Communications, Vol. 3, No. 1-2, January June, 2013. pp. $68-72$.

8. Slusar, V. I. (2008) "Military communications of NATO countries: problems of modern technologies", Electronics: science, technology, business, No 4, pp. 66 - 71. available at: http://www.electronics.ru/files/article_pdf/0/article_403_181.pdf (last accessed October 22, 2019).

9. Bessai H. (2005), MIMO Signals and Systems, USA, NY: Springer science and Business Media, $206 \mathrm{p}$.

10. Kuvshinov O. V. and Minochkin D. A. (2006) "Analysis of the characteristics of radio access systems with MIMO technology", Collection of scientific works of the Military institute of Kyiv national Taras Shevchenko university. - Publ. No 3, Kyiv.: MIKNU, pp. $51-56$.

11. Romanenko, I. and Shyshatskyi, A (2017), "Analysis of modern condition of military radiocommunication system", Advanced Information Systems, Vol. 1, No. 1, pp. 28-33, DOI: https://doi.org/10.20998/2522-9052.2017.1.05

12. Zhuk, O.G., Shyshatskiy, A.V., Zhuk, P.V. and Zhyvotovskyi, R.M. (2017), "Methodological substances of management of the radio-resource managing systems of military radio communication", Information Processing Systems, Vol. 5(151), pp. 16-25, DOI: https://doi.org/10.30748/soi.2017.151.02.

13. Zhyvotovskyi, R.M., Shyshatskyi, A.V.and Petruk, S.N (2017). "Structural-semantic model of communication channel". 4th International Scientific-Practical Conference "Problems of Infocommunications. Science and Technology” (PICS\&T-2017). 10-13 October 2017. Kharkiv, Ukraine. P. 524 - 529. DOI: http://doi.org/10.1109/INFOCOMMST.2017.8246454.

14. Petruk, S.N., Zhyvotovskyi, R.M. and Shyshatskyi, A.V(2018). "Mathematical Model of MIMO". 5th International Scientific-Practical Conference "Problems of Infocommunications. Science and Technology" (PICS\&T-2018). 9-12 October 2018. Kharkiv, Ukraine. pp. 7 - 12. DOI: http://doi.org/10.1109/INFOCOMMST.2018.8632163. 
Відомості ПРо АВторів / АвоUт тHE AUTHORS

Животовський Руслан Миколайович - кандидат технічних наук, старший дослідник, начальник науково-дослідного відділу, Центральний науково-дослідний інституг озброєння та військової техніки Збройних Сил України, Київ, Україна; Ruslan Zhyvotovskyi - Candidate of Technical Sciences, Senior Research, Chief of Scientific Research Department, Central Research Institute of Weapons and Military Equipment of Armed Forces of Ukraine, Kyiv, Ukraine; e-mail: Ruslan_zhyv@ukr.net; ORCID ID: http://orcid.org/0000-0002-2717-0603

Моміт Олександр Сергійович - начальник відділу, військова частина А2393, Одеса, Україна; Alexander Momit - Head of Department, Military unit A 2393, Odessa, Ukraine; e-mail: momit sasha@ukr.net; ORCID: https://orcid.org/0000-0002-8901-7006

Онбінський Ярослав Олександрович - начальник служби Головне управління Національної гвардії України, Київ, Україна;

Yaroslav Onbinskyi - Head of Department, General Directorate of the National Guard of Ukraine, Kyiv, Ukraine; e-maili.yakhno@ngu.gov.ua; ORCID: https://orcid.org/0000-0003-1009-3709

Ляшенко Ганна Тарасівна - науковий співробітник науково-дослідного відділу, Військовий інститут телекомунікацій та інформатизації імені Героїв Крут, Київ, Україна;

Anna Lyashenko - Research Associate, Military institute of telecommunications and informatization named after Heroes of Kruty, Kyiv, Ukraine;

e-mail: Anutka-2-0-0-8@ukr.net; ORCID ID: https://orcid.org/0000-0002-5318-8663

\section{Аналіз відомих методів контролю стану каналів систем зв'язку 3 навмисними завадами та селективними завмираннями \\ Р. М. Животовський, О. С. Моміт, Я. О. Онбінський, Г. Т. Ляшенко}

Анотація. При проектуванні адаптивних систем радіозв'язку залежно від їх призначення вирішується завдання оптимізації одного 3 показників ефективності при встановлених обмеженнях на інші. В свою чергу, розробка $\mathrm{i}$ впровадження адаптивних методів інформаційного обміну вимагають створення ефективних процедур контролю та прогнозування стану каналів зв'язку і якості передачі інформації. Враховуючи бурхливий розвиток засобів радіоелектронної боротьби, розширення переліку завад, що можуть бути створені зазначеними комплексами, набувають великої актуальності подальші наукові дослідження з питання створення нових методів контролю стану каналу зв'язку. В зазначеному дослідженні авторами був проведений аналіз характеристик основних методів оцінки стану каналів зв'язку. В ході зазначеного аналізу авторами були використані загальнонаукові методи: аналіз та синтез, основні положення теорії зв’язку, теорії передачі даних, теорії просторово-часового кодування, теорії завадостійкості, теорії сигнально-кодових конструкцій та інші. Проведений авторами статті аналіз відомих методів оцінювання стану каналу багатоантенних систем зв'язку показав, що в відомих наукових працях відсутнє наступне: паралельна оцінка стану каналу за декількома показниками; отримання узагальненої оцінки стану каналу; постійне оцінювання декількох характеристик в режимі реального часу; одночасне оцінювання як лінії вниз, так і лінії вгору; для оцінки не використовується поєднання імпульсної характеристики стану каналу, частотної характеристики стану каналу та ймовірності бітової помилки. Встановлено те, що на даний момент не існує універсального методу контролю стану каналів багатоантенних систем радіозв'язку, котрий б давав точну, швидку оцінку стану каналу в реальному часі, мав би можливість ефективної адаптації в каналі з нестаціонарними параметрами.

Ключов і слова : відношення сигнал/шум; швидкість передачі інформації; ймовірність бітової помилки; просторово-часова обробка; система МІМО; паралельні канали.

\section{Анализ известных методов контроля состояния каналов систем святи с преднамеренными помехами и селективными замираниями \\ Р. Н. Животовский, А. С. Момит, Я. А. Онбинский, А. Т. Ляшенко}

Аннотация. При проектировании адаптивных систем радиосвязи в зависимости от их назначения решается задача оптимизации одного из показателей эффективности при установленных ограничениях на другие. В свою очередь, разработка и внедрение адаптивных методов информационного обмена требует создания эффективных процедур контроля и прогнозирования состояния каналов связи и качества передачи информации. Учитывая бурное развитие средств радиоэлектронной борьбы, расширения перечня помех, которые могут быть созданы указанными комплексами, приобретают большую актуальность дальнейшие научные исследования в вопросе создания новых методов контроля состояния канала связи. В указанном исследовании авторами был проведен анализ характеристик основных методов оценки состояния каналов связи. В ходе указанного анализа авторами были использованы общенаучные методы: анализ и синтез, основные положения теории связи, теории передачи данных, теории пространственно-временного кодирования, теории помехоустойчивости, теории сигнально-кодовых конструкций и др. Проведенный авторами статьи анализ известных методов оценки состояния канала многоантенных систем связи показал, что в известных научных трудах отсутствует следующее: параллельная оценка состояния канала по нескольким показателям; получение обобщенной оценки состояния канала; постоянное оценивание нескольких характеристик в режиме реального времени; одновременная оценка как линии вниз, так и линии вверх; для оценки не используется сочетание импульсной характеристики состояния канала, частотной характеристики состояния канала и вероятности битовой ошибки. Установлено, что на данный момент не существует универсального метода контроля состояния каналов многоантенных систем радиосвязи, который бы давал точную, быструю оценку состояния канала в реальном времени, имел бы возможность эффективной адаптации в канале с нестационарными параметрами.

Ключевые слова: отношение сигнал/шум; скорость передачи информации; вероятность битовой ошибки; пространственно-временная обработка; система МIMO; параллельные каналы. 